doi: $10.7250 /$ iscconstrs.2014.02

\title{
POSSIBILITIES OF USE OF INDUSTRIAL WASTE IN ROAD CONSTRUCTION ON THE TERRITORY OF THE LENINGRAD REGION
}

\author{
Alexander Alhimenko', Mikhail Romanov ${ }^{2}$ \\ ${ }^{1}$ Department of Hydrotechnic and Landscape Constructions, Civil Engineering Institute, Saint-Petersburg State \\ Polytechnical University, Polytehnicheskaya Str. 29,195251 Saint-Petersburg, Russia \\ ${ }^{2}$ Department of Civil Engineering and Applied Ecology, Civil Engineering Institute, Saint-Petersburg State \\ Polytechnical University, Polytehnicheskaya Str. 29,195251 Saint-Petersburg, Russia \\ E-mail:1alexal@cef.spbstu.ru; ${ }^{2}$ rom@cef.spbstu.ru (correspondingauthor)
}

\begin{abstract}
The main results of the joint international project №2006/123-438 “ECOROAD” (South-East Finland - Russia Neighborhood Programme) are presented in this paper. Coordinator of the project is Lappeenranta University of Technology, main partners are Saint-Petersburg State Polytechnical University and Saint Petersburg State Technological University of Plant Polymers. The project was implemented with support of the Committee of Natural Resources and Environmental Protection of the Leningrad Region, Committee of Road Maintenance and Transport of the Leningrad Region, and some enterprises of the Leningrad Region. Important data and recommendations for practical use of industrial waste of enterprises of the Leningrad Region (fly ashes, metallurgic slag, etc.) were received during implementation of the project.
\end{abstract}

Keywords: industrial waste, road constructions, fly ashes, metallurgic slag, ecological applicability, geotechnical experiments.

\section{Introduction}

In the Russian and European Environmental Laws the use of industrial waste is considered to be among priorities. The use of industrial waste makes it possible to accomplish the following goals:

- to realize basic principles of the state environmental policy in the field of environmental protection;

- to decrease the use of natural resources;

- to reduce negative impact on the environment owing to waste disposal on special polygons and landfills;

- to improve economic indicators of industrial enterprises activities.

Road construction, grading of territories and engineering preparation of soils are among the most important objects for the industrial waste utilization (Mroueh and Wahlstrom 2002; Sybilski 2004; Lahtinen 2007).

\section{Goal and tasks of the ECOROAD project}

Goal of Tacis-part of the ECOROAD project is to create scientific basis and practical prerequisites for waste and by-product usage in regular road construction in North-West Russia (Romanov 2007).

To achieve the goal the following tasks should be solved in the project:

- to study the experience of Finnish scientists in the usage of by-products for construction of small roads and engineering preparation of territories (Lahtinen 2007; Kalliohpaa 2007; Vallius 2007), and also facilitate active exchange of knowledge in this sphere;

- to study and solve questions, connected with production of waste and by-products of the demanded quality, and also their transportation (logistics task) and storage of by-products;

- analysis of chemical and physical parameters of waste samples to ensure ecological safety of their utilization;
- analysis of chemical and physical parameters of mixtures used for road construction in order to get materials with high operating characteristics (durability, etc);

- elaboration of scientifically justified recommendations (technological manual) for using wastes for road construction in Russia in accordance with Russian legislation;

- justification of the best available technology of waste utilization for road construction taking into account economic, ecological and social factors (life cycle assessment);

- all kinds of assistance to ensure ecological safety and sustainable development in the region of the program, dissemination of ecological knowledge and viable technologies.

\subsection{Selection of waste types}

The waste types required to be studied within the ECOROAD Project have been chosen and determined by the partners while taking into account structures and capacities of the enterprises existing in the Leningrad Region as well as when considering the stands of the Committee for Natural Resources and Environmental Protection of the Leningrad Region and economic entities - waste owners.

The total number of waste types sampled at the enterprises is 12 . The list of the sampled waste types is given in Table 1 (Alhimenko et al. 2008).

As it has been established upon inventorying, waste generation sources such as boilers and alternative equipment are continuously operating. Waste generation is mainly characterized by continuous dynamics. Any equipment shut-downs (planned outages) are due to the need in its scheduled preventive maintenance. 
Table 1. List of the waste types sampled and the sources of their generation.

\begin{tabular}{|c|c|c|}
\hline No. & Waste type & $\begin{array}{l}\text { Enterprise - waste } \\
\text { generation source }\end{array}$ \\
\hline 1 & $\begin{array}{l}\text { Flotation sludge cake of the } \\
\text { repulping department }\end{array}$ & $\begin{array}{l}\text { SCA Hygiene } \\
\text { Products Russia }\end{array}$ \\
\hline 2 & $\begin{array}{l}\text { Light polymeric waste of } \\
\text { the repulping plant }\end{array}$ & $\begin{array}{l}\text { SCA Hygiene } \\
\text { Products Russia }\end{array}$ \\
\hline 3 & $\begin{array}{l}\text { Bottom ash after waste } \\
\text { water treatment facilities } \\
\text { sludge combustion }\end{array}$ & OAO "Svetogorsk" \\
\hline 4 & $\begin{array}{l}\text { Fly ash after waste water } \\
\text { treatment facilities sludge } \\
\text { combustion }\end{array}$ & OAO "Svetogorsk" \\
\hline 5 & $\begin{array}{l}\text { Sludge of waste water } \\
\text { treatment facilities }\end{array}$ & OAO "Spb KPK" \\
\hline 6 & $\begin{array}{l}\text { Lime mud from the } \\
\text { bleaching department }\end{array}$ & $\begin{array}{l}\text { OAO "Syassky Pulp } \\
\text { \& Paper Mill" }\end{array}$ \\
\hline 7 & $\begin{array}{l}\text { Fly ash from the boiler for } \\
\text { wood residue combustion }\end{array}$ & $\begin{array}{c}\text { Novolisino Forestry } \\
\text { College }\end{array}$ \\
\hline 8 & $\begin{array}{l}\text { Cinder from the boiler for } \\
\text { wood residue combustion }\end{array}$ & $\begin{array}{c}\text { Novolisino Forestry } \\
\text { College }\end{array}$ \\
\hline 9 & $\begin{array}{l}\text { Fly ash from the boiler for } \\
\text { wood residue combustion }\end{array}$ & $\begin{array}{l}\text { OAO "Svetwood- } \\
\text { Tikhvin" }\end{array}$ \\
\hline 10 & $\begin{array}{l}\text { Cinder of boiler for wood } \\
\text { residue combustion }\end{array}$ & $\begin{array}{l}\text { OAO "Svetwood- } \\
\text { Tikhvin" } \\
\end{array}$ \\
\hline 11 & $\begin{array}{l}\text { Metallurgic slag from the } \\
\text { ferroalloy plant }\end{array}$ & $\begin{array}{c}\text { OAO "Tikhvin } \\
\text { Ferroalloy Plant" }\end{array}$ \\
\hline 12 & $\begin{array}{l}\text { Dust form scrubbing and } \\
\text { suction systems of the } \\
\text { ferroalloy plant }\end{array}$ & $\begin{array}{l}\text { OAO "Tikhvin } \\
\text { Ferroalloy Plant" }\end{array}$ \\
\hline
\end{tabular}

1.2. Results as basics for substantiating environmental suitability of waste types for their use in road construction and related fields

After testing of their ecological applicability, the following waste grades can be recommended for use (Alhimenko et al. 2008):

1) fly and bottom ash from the OAO Svetogorsk refuse boiler operating on wood residue and sludge of the biological wastewater treatment system;

2) sludge cake of the flotation plant at the SCA Hygiene Products Russia;

3) light polymeric waste after the repulping process at the SCA Hygiene Products Russia;

4) fly ash and cinder from a refuse boiler operating on wood residue at the Novolisino Forestry College;

5) sewage sludge from waste water treatment facilities of OAO SPb KPK;

6) repulping fibrous waste at $\mathrm{OAO} \mathrm{SPb} \mathrm{KPK}$;

7) fly ash and cinder from a refuse boiler operating on wood residue at ZAO Tikhvin-Svetwood;

8) flushing slag generated at an electric ferroalloying furnace at ZAO Tikhvin Ferroalloy Plant;

9) dust of gas cleaning and aspiration systems of ZAO Tikhvin Ferroalloy Plant;

10) lime mud (lime slaking waste) generated at the lime cream plant of OAO Syassky Pulp and Paper Mill.

Industrial wastes are transferred to Saint-Petersburg State Polytechnical University after testing their ecological applicability in Saint Petersburg State Technological University of Plant Polymers.

\subsection{Geotechnical investigations}

The following samples were selected for geotechnical experiments under quantitative data of waste volumes produced at the enterprises and as a medium for the tests on ecological risks undertaken:

- slag of ferroalloy production (JSC "Ferroalloy Tikhvin factory");

- wood fly and benthic ash (JSC "Svetogorsk");

- fibrous waste from floater ("Co Ltd Hygiene Products Russia");

- moist ash (JSC “Svetwood-Tikhvin");

- coal ash of hydro expulsion heat plant power № 17.

In this group the application of the crushed slag stone of ferroalloy production is different. Its properties were determined according to GOST 8269.0-97.

Practicability of using fly ash and slag/ash mixtures of slag heaps is established in each case on the basis of the feasibility study by taking into account ash quality and slag/ash mixtures quality, transportation range, costs and other factors.

Fly ash is used for construction of stabilized roads bases and pavements in the capacity of:

a) active hydraulic admixture, i.e. active component of mixed binding agent in aggregate with a cement or lime;

b) slow-early-strength binding agent itself.

Slag/ash mixtures are used in road construction in the capacity of:

a) material for the construction of the road bed earth fill;

b) low-activity hydraulic admixture in aggregate with cement for soil stabilization on the roads categories III-IV. Low-activity hydraulic admixtures are such kind of substances (slag/ash mixtures) which are between inert floured admixtures and active mineral hydraulic admixtures. In the course of time such substances (slag/ash mixtures) are capable to rather slowly bind free lime which is generated by hardening of Portland cement.

Freeze-thaw resistance should be considered as the main evaluation indicator of slag/ash mixtures suitableness for roadbed construction. Both the slag/ash mixture and the soil freeze-thaw resistance are characterized by relative frost heave $\mathrm{K}_{\mathrm{hv}}$ which is a percentage relation vertical heave deformation by sample freezing to its original height.

Slag/ash mixtures with relative frost heave value (not more than $3 \%$ ) are used for construction of roadbed earth fill without limits. 
Slag/ash mixtures with relative frost heave value (from $3 \%$ to $10 \%$ ) are allowed for roadbed earth fill with compulsory project for stabilization of the roadbed and especially of its upper layers in the freezing zone.

Slag/ash mixtures with relative frost heave value (over $10 \%$ ) aren't used for roadbed earth fill construction.

Slag/ash mixture freeze-thaw resistance can be assessed roughly by their particles (smaller than $0.05 \mathrm{~mm}$ ) content. If slag/ash mixture particle (smaller than $0.05 \mathrm{~mm}$ ) content is not more than $5 \%$ it can be considered that relative frost heave value would not be more than $3 \%$.

Uncemented clastic soils of different particle-size distribution, sands and also sandy loam soil and other materials which are the run of crushed stone binding with ashes and slag/ash mixtures solidify and get necessary stabilization and freeze-thaw resistance during a long period of time. Therefore, the suitability of the final selected mixture composition of such stabilized materials for industrial construction is established by stability factor of water-saturated samples that have been solidified during 90 days in wet conditions according to the requirements shown in Table 2.

Table 2. Indexes of Stabilized Materials PhysicalMechanical Properties.

\begin{tabular}{|c|c|c|c|}
\hline \multirow[t]{2}{*}{ Index } & \multicolumn{3}{|c|}{ Strength Grade } \\
\hline & I & II & III \\
\hline $\begin{array}{l}\text { Ultimate compression } \\
\text { strength of water- } \\
\text { saturated samples } \\
\text { ageing } 90 \text { days, MPa }\end{array}$ & $5.84-3.92$ & $\begin{array}{c}3.92- \\
1.96\end{array}$ & $\begin{array}{c}1.96- \\
0.98\end{array}$ \\
\hline $\begin{array}{l}\text { Ultimate tensile } \\
\text { bending strength of } \\
\text { water-saturated samples } \\
\text { ageing } 90 \text { days, } \mathrm{MPa}\end{array}$ & 0.98 & 0.59 & 0.20 \\
\hline $\begin{array}{l}\text { Freezing resistance } \\
\text { factor of samples } \\
\text { ageing } 90 \text { days (relation } \\
\text { of ultimate } \\
\text { compression strength } \\
\text { after freezing- } \\
\text { defrosting to the } \\
\text { ultimate compression } \\
\text { strength of the water- } \\
\text { saturated samples), not } \\
\text { less than }\end{array}$ & 0.75 & 0.70 & 0.65 \\
\hline $\begin{array}{l}\text { Sample moisture after } \\
\text { freezing-defrosting, } \\
\text { mass } \% \text {, not more than }\end{array}$ & $\begin{array}{l}2 \% \text { of over } \\
\text { optimum } \\
\text { moisture and } \\
\text { compaction }\end{array}$ & $\begin{array}{r}\text { of over } \\
\text { mo } \\
\text { and co }\end{array}$ & $\begin{array}{l}\text { ptimum } \\
\text { ure } \\
\text { paction }\end{array}$ \\
\hline
\end{tabular}

The ash used for soil stabilization as a binding agent itself or as an active component of a mixed binding agent has to be a fly ash (Table 3 ).
Table 3. Requirements to an ash used for soil stabilization as a binding agent or as an active component.

\begin{tabular}{|c|c|c|c|}
\hline \multirow{3}{*}{$\begin{array}{l}\text { Normalized } \\
\text { factors }\end{array}$} & \multicolumn{3}{|c|}{ Ash requirements } \\
\hline & \multirow{2}{*}{$\begin{array}{l}\text { Ash as a } \\
\text { slow- } \\
\text { early- } \\
\text { strength } \\
\text { binding } \\
\text { agent } \\
\text { itself }\end{array}$} & \multicolumn{2}{|c|}{$\begin{array}{l}\text { Ash as an active } \\
\text { component of the mixed } \\
\text { binding agent }\end{array}$} \\
\hline & & $\begin{array}{l}\text { in aggregate } \\
\text { with a } \\
\text { cement }\end{array}$ & $\begin{array}{c}\text { in } \\
\text { aggregate } \\
\text { with a lime }\end{array}$ \\
\hline $\begin{array}{l}\text { Free quicklime } \\
\text { content, } \%\end{array}$ & $\begin{array}{c}\text { Not less } \\
\text { than } 8\end{array}$ & $\begin{array}{l}\text { Not more } \\
\text { than } 4\end{array}$ & $\begin{array}{c}\text { Free } \\
\text { quicklime } \\
\text { content, } \%\end{array}$ \\
\hline $\begin{array}{l}\text { Specific } \\
\text { surface, } \mathrm{cm}^{2} / \mathrm{g}\end{array}$ & $\begin{array}{l}\text { Not less } \\
\text { than } 3000\end{array}$ & $\begin{array}{l}\text { Not less } \\
\text { than } 3000 \\
\end{array}$ & $\begin{array}{l}\text { Not less } \\
\text { than } 3000\end{array}$ \\
\hline $\begin{array}{l}\text { Sulphide and } \\
\text { sulphate } \\
\text { content (in } \\
\text { terms of } \\
\left.\mathrm{SO}_{3}\right) \% \\
\end{array}$ & $\begin{array}{l}\text { Not more } \\
\text { than } 6\end{array}$ & $\begin{array}{l}\text { Not less } \\
\text { than } 3\end{array}$ & - \\
\hline $\begin{array}{l}\text { Loss of } \\
\text { ignition, } \%\end{array}$ & $\begin{array}{l}\text { Not more } \\
\text { than } 5\end{array}$ & $\begin{array}{l}\text { Not less } \\
\text { than } 10\end{array}$ & $\begin{array}{l}\text { Not less } \\
\text { than } 10\end{array}$ \\
\hline
\end{tabular}

Ash (used as a binding agent itself or active component of the mixed binding agent in aggregate with a cement or lime) satisfying Table 3 requirements is used for the construction of stabilized road bases on the roads of all categories without limits and also for road pavements of IV-V road categories.

Fly ash, the specific surface of which equals $1600 \mathrm{~cm}^{2} / \mathrm{g}$, is permitted for use in construction of road bases (roads categories III-V) and of road pavements (roads categories IV-V) if their content of free quicklime, sulphide and sulphate and loss of ignition correspond to the requirements set in Table 3.

Calculated values of modulus of elasticity of soils and locally manufactured materials stabilized by fly ash in aggregate with Portland cement or with lime or without it and also by slag/ash mixtures in aggregate with Portland cement are established dependent on the stabilized soil and the used binding agent. Table 4 presents this data (Alhimenko et al. 2008).

Table 4. Calculated Values of Modulus of Elasticity of Stabilized Materials and Soils.

\begin{tabular}{l|l|l}
\hline \begin{tabular}{l} 
Soils and Materials, $\begin{array}{l}\text { Subjected to } \\
\text { Stabilization }\end{array}$ \\
\cline { 2 - 3 }
\end{tabular} & \multicolumn{2}{|c}{$\begin{array}{c}\text { Calculated Values of Modulus of } \\
\text { Elasticity (MPa) additions of }\end{array}$} \\
\cline { 2 - 3 } $\begin{array}{l}\text { aggregate with } \\
\text { Portland } \\
\text { cement (ash } \\
\text { specific surface } \\
\text { in both } \\
\text { additions not } \\
\text { less than 3,000 } \\
\mathrm{cm} / \mathrm{g})\end{array}$ & $\begin{array}{l}\text { ash in aggregate } \\
\text { with lime (ash } \\
\text { specific surface } \\
\text { not less than } \\
\left.3,000 \mathrm{~cm}^{2} / \mathrm{g}\right), \text { ash } \\
\text { (ash specific } \\
\text { surface not less } \\
\left.\text { than } 1,600 \mathrm{~cm}^{2} / \mathrm{g}\right) \\
\text { and slag/ash } \\
\text { mixtures }(\mathrm{specific} \\
\text { surface not less } \\
\left.\text { than } 1,600 \mathrm{~cm}^{2} / \mathrm{g}\right)\end{array}$ \\
\hline
\end{tabular}




\begin{tabular}{|c|c|c|}
\hline $\begin{array}{l}\text { Macrofragmental } \\
\text { uncemented soils, } \\
\text { soils in aggregate } \\
\text { with gravel, soils in } \\
\text { aggregate with } \\
\text { crushed stone near } \\
\text { optimal content, } \\
\text { fine and coarse } \\
\text { sands, uniform } \\
\text { sands }\end{array}$ & $392-785$ & $392-588$ \\
\hline $\begin{array}{l}\text { Macrofragmental } \\
\text { uncemented soils, } \\
\text { soils in aggregate } \\
\text { with gravel, soils in } \\
\text { aggregate with } \\
\text { crushed stone of } \\
\text { nonoptimal content }\end{array}$ & $392-785$ & 441-637 \\
\hline $\begin{array}{l}\text { Uniformed sands of } \\
\text { different fraction } \\
\text { sizes, very fine } \\
\text { sand, sandy loam } \\
\text { (plasticity index } \\
\text { equals 3) }\end{array}$ & $245-687$ & $196-490$ \\
\hline $\begin{array}{l}\text { Sandy loams near } \\
\text { optimal content, } \\
\text { coarse, fine and } \\
\text { very fine sandy } \\
\text { loams }\end{array}$ & $294-687$ & $196-490$ \\
\hline
\end{tabular}

Besides the calculated value of modulus of elasticity (Table 4) of all types of stabilized materials and soils, the second calculation index is used. The second calculation index is ultimate tensile bending strength dependent on strength grade:

grade I - not less than $0.39 \mathrm{MPa}$;

grade II - not less than $0.20 \mathrm{MPa}$;

grade III - not less than $0.10 \mathrm{MPa}$.

Volumes of ash (used as a binding agent itself or active component of mixed binding agent in aggregate with a cement or lime) satisfying Table 3 requirements are established:

a) not less than $20 \%$ of mixture mass - ash as a binding agent itself;

b) not less than $15-20 \%$ of mixture mass in aggregate with $4-6 \%$ cement of mixture mass, lime addition is within $5-8 \%$ of mixture mass (ash as an active component of mixed binding agent)

Ash and slag/ash volumes of hydroexpulsion which don't satisfy Table 3 requirements are established not less than $15-25 \%$ of mass mixture in aggregate with cement 5 $10 \%$ of mixture mass.

For facilitating the solidification process and increasing the strength index of soils stabilized by ash as an active binding agent itself it is recommended to add calcium chloride amounting to 4-6\% of mixture mass.

During sandy loam stabilization by ash addition used in the capacity of an active binding agent itself, free lime content in the ash should not be less than $15 \%$ of ash mass. Ash volume should be $20-25 \%$ of mixture mass.

In some cases for facilitating the structurization processes and freeze-thaw resistance of fine sandy loam soils stabilized by ash it is recommended to add the caustic soda amounting to $0.7-1 \%$ of dry soil mass.
The following two types of soils, which are subject to consolidation grouting, were tested: fine sand and loam. Portland cement grade 400 was chosen as a certified binding agent in mixture with wastes.

In view of the foregoing considerations, the mixtures of materials, binding agents and ashes chosen for the preliminary test are the following (Alhimenko et al. 2008):

1. The fly ash of «Svetogorsk» JSC:

- pulverescent sand+3\% of cement;

- pulverescent sand+6\% of cement;

- loam+5\% of cement;

- loam+10\% of cement;

- pulverescent sand $+3 \%$ of cement $+10 \%$ of ash;

- pulverescent sand+6\% of cement $+10 \%$ of ash;

- loam+5\% of cement $+15 \%$ of ash;

- loam $+10 \%$ of cement $+15 \%$ of ash;

- pulverescent sand+6\% of cement $+10 \%$ of fibers;

- loam $+10 \%$ of cement $+10 \%$ of fibers.

2. The bottom ashes of «Svetogorsk» JSC:

- pulverescent sand $+6 \%$ of cement $+20 \%$ of ash;

- loam+10\% of cement $+20 \%$ of ash.

3. The ash-and-slag mixture of «Svedvud-Tikhvin» LLC:

- pulverescent sand $+6 \%$ of cement $+20 \%$ of ash;

- $10 a m+10 \%$ of cement $+20 \%$ of ash.

6 test samples were taken from these mixtures. The minimal quantity of cementations additive to provide the material qualities meeting the Table 2 requirements is taken as the optimum.

Ash and soil mixtures were agitated in a laboratory muller mixer in order to guarantee comparability of the test results.

For determination of physical-mechanical properties of the material, cylinder and beam-shaped specimens were prepared by compacting the mixture in steel templates.

The results of strength test are shown below (Table 5).

Table 5. Results of strength test.

\begin{tabular}{l|c|c}
\hline \multicolumn{1}{c|}{ A type of mixture } & $\begin{array}{c}\text { The ultimate } \\
\text { compression } \\
\text { strength of the } \\
90 \text { days aquic } \\
\text { samples, MPa }\end{array}$ & $\begin{array}{c}\text { The ultimate } \\
\text { tensile } \\
\text { strength of the } \\
90 \text { days aquic } \\
\text { samples in } \\
\text { bending, MPa }\end{array}$ \\
\hline $\begin{array}{l}\text { The fly ash of } \\
\text { «Svetogorsk» JSC: }\end{array}$ & 1.8 & 0.2 \\
$\begin{array}{l}\text { a) pulverescent } \\
\text { sand+3\% of cement; } \\
\text { b) pulverescent } \\
\text { sand+6\% of cement; } \\
\text { c) loam+5\% of cement; }\end{array}$ & 3.2 & 0.5 \\
d) loam+10\% of \\
cement; \\
$\begin{array}{l}\text { e) pulverescent } \\
\text { sand+3\% of } \\
\text { cement+10\% of ash; }\end{array}$
\end{tabular}




\begin{tabular}{|c|c|c|}
\hline $\begin{array}{l}\text { h) loam }+10 \% \text { of } \\
\text { cement }+15 \% \text { of ash; } \\
\text { i) pulverescent } \\
\text { sand }+6 \% \text { of } \\
\text { cement }+10 \% \text { of fibers; } \\
\text { j) loam }+10 \% \text { of } \\
\text { cement }+10 \% \text { of fibers; }\end{array}$ & $\begin{array}{l}3.0 \\
1.8\end{array}$ & 0.2 \\
\hline $\begin{array}{l}\text { The bottom ashes of } \\
\text { «Svetogorsk» JSC: } \\
\text { a) pulverescent } \\
\text { sand }+6 \% \text { of } \\
\text { cement }+20 \% \text { of ash; } \\
\text { b) loam }+10 \% \text { of } \\
\text { cement }+20 \% \text { of ash; }\end{array}$ & 2.0 & 0.2 \\
\hline $\begin{array}{l}\text { The ash-and-slag } \\
\text { mixture of «Svedvud- } \\
\text { Tikhvin» LLC: } \\
\text { a) pulverescent } \\
\text { sand }+6 \% \text { of } \\
\text { cement }+20 \% \text { of ash; } \\
\text { b) loam }+10 \% \text { of cement } \\
+20 \% \text { of ash. }\end{array}$ & 1.8 & 0.1 \\
\hline
\end{tabular}

Calculations, which are required to estimate the value of relational heaving of frosty soils regulated by binding agents and ashes, were carried out according to DBS (departmental building specifications) procedure 185-75. This procedure consists in freezing of material samples and deformation measurement of their frosty upheaval in conditions similar to the situation when soil heaving takes place during frost penetration into roadbed. In this case the soil test was carried out in a chamber with inside air temperature

$-5^{\circ} \mathrm{C}$.

D. I. Znamenskiy's «PNZ» device (resized) was applied in the upheaval test operation to estimate a swelling index of soils.

The ready-fitted device was chambered into the freezer. Cooling of the sample came of a punch, i.e. from above. During the test operation the frosty heaving deformation was seen to and measured by the instrumentality of an indicator.

The test resumed until indicator's registration came to the constant value that attested the end of the sample frost penetration.

On the morrow of the test, relying on the frosty heaving deformation fixtures the value of relational frosty soil heaving $\left(\mathrm{K}_{\mathrm{def}}\right)$ was to be estimated by the formula:

$$
K_{\text {def }}=\frac{\Delta h}{h} \times 100 \%,
$$

where $\Delta \mathrm{h}$ is a value of the sample heaving, $\mathrm{mm} ; h$ is an initial height of the sample, $\mathrm{mm}$.

The mixture used in the test involved loam $+5 \%$ of cement $+15 \%$ of ash of «Svetogorsk» JSC. The result $2.5 \%$ makes the chosen mixture compositions applicable to roadbed constructions because of the sufficient heaving index.

For determination of other parameters of slag/ash mixtures (modulus of elasticity and compaction, stiffness, etc.) standard methods according to the existing GOST were used.

\section{Conclusions}

Analyzing the results of testing the incidental products of the Leningrad Region industry that were obtained within ECOROAD project we can make the following conclusions:

1. Crushed stone made of «TFZ» JSC ferroalloy production slag is applicable to any construction work except for a ballast layer of a railway ways due to the big contents of metal and due to high electroconductivity.

2. The «Svetogorsk» JSC fly ash from combusted bark can be used in the capacity of an active component in the binding mixture. Structures for stabilization fine sand and loam with addition of flying ashes of $10 \%$ and $15 \%$ give an essential gain of durability on compression and stretching.

3. The bottom ash-and-slag mixture of «Svetogorsk» JSC and the wet ash-and-slag mixture of «SvedvudTikhvin» LLC are applicable for the creation of roadbed embankment as an inert material in the mixtures with additives of Portland cement in amount up to $20 \%$.

4. Fiber-wastes of the "SCA Hygiene Products Russia» LLC flotation plant are applicable for mixtures for roadbeds as materials for disperse reinforcing together with Portland cement (binder).

\section{References}

Lahtinen, P., 2007. Use of industrial wastes in road construction. In Abstract Book of the 1st International Workshop "Using of Industrial Wastes and By-products in Road Construction", May 31 - June 1, 2007, SaintPetersburg, Russia, pp.14-24.

Kalliohpaa, T., 2007. Road construction as a recycled products consumer. In Abstract Book of the $1^{\text {st }}$ International Workshop "Using of Industrial Wastes and By-products in Road Construction", May 31 - June 1, 2007, Saint-Petersburg, Russia, pp.12-14.

Vallius, P., 2007. Case: renovation of gravel road by using dry bark residue ash. In Abstract Book of the 1st International Workshop "Using of Industrial Wastes and By-products in Road Construction", May 31 - June 1, 2007, SaintPetersburg, Russia, pp. 28-37.

Sybilski, D., 2004. Use of Industrial Waste Materials in Road Construction in Poland. In E. Vázquez, et al. (Eds.). International RILEM Conference on the Use of Recycled Materials in Building and Structures. RILEM Publications SARL, pp. $351-360$.

Mroueh, U. M.; Wahlstrom, M., 2002. By-Products and Recycled Materials in Earth Construction in Finland ? An Assessment of Applicability. Resources, Conservation and Recycling, 35, pp. 117 ? 129.

http://dx.doi.org/10.1016/S0921-3449(01)00126-4

Alhimenko, A.I.; Churillo, A.V.; Romanov, M.V. et al., 2008. Technical recommendations on the use of industrial waste in road construction on the territory of the Leningrad Region. Technical Report of ECOROAD project. Saint-Petersburg: Publishing house of Saint-Petersburg State Polytechnical University, $50 \mathrm{p}$.

BRS 218.046-01. Branch road standarts. Designing of nonrigid road carpets. Moscow: State service of road maintenance of the Ministry of transport of the Russian Federation. 2001 (in Russian). Available at: 
http://www.stroyoffis.ru/odn_otraslevie/odn_218_046_01/od n_218_046_01.php

GOST 8269.0-97. The interstate standard. Break-stone and gravel from dense rocks and waste of industrial production for civil engineering. Methods of physicomechanical tests. Moscow, 1997 (in Russian). Available at:

http://www.docload.ru/Basesdoc/5/5182/index.htm

Romanov, M.V., 2007. Perspectives of use of paper-mill industry wastes for road construction in Leningrad Region. In Abstract Book of the 1st International Workshop "Using of Industrial Wastes and By-products in Road Construction", May 31 - June 1, 2007, Saint-Petersburg, Russia, pp.26-27.
DBS 185-75. Technical instructions on use of fly ashes and ashslag mixtures from burning of various kinds of solid fuel for construction of ground carpets and construction of the road underlayments and coverings. Moscow: Ministry of transport building. 1976 (in Russian). Available at:

http://www.docload.ru/Basesdoc/5/5572/index.htm 